\title{
Alice de Georges-Métral, Poétique de l'excédent dans la narration aurevillienne
}

\section{Maria Emanuela Raffi}

\section{(2) OpenEdition}

1 Journals

\section{Edizione digitale}

URL: http://journals.openedition.org/studifrancesi/7658

DOI: ERREUR PDO dans/localdata/www-bin/Core/Core/Db/Db.class.php L.34 : SQLSTATE[HYO00]

[2006] MySQL server has gone away

ISSN: 2421-5856

\section{Editore}

Rosenberg \& Sellier

\section{Edizione cartacea}

Data di pubblicazione: 1 décembre 2009

Paginazione: 654-655

ISSN: 0039-2944

\section{Notizia bibliografica digitale}

Maria Emanuela Raffi, «Alice de Georges-Métral, Poétique de l'excédent dans la narration aurevillienne», Studi Francesi [Online], 159 (LIII | III) | 2009, online dal 30 novembre 2015, consultato il 08 janvier 2021. URL: http://journals.openedition.org/studifrancesi/7658 ; DOI: https://doi.org/ERREUR PDO dans / localdata/www-bin/Core/Core/Db/Db.class.php L.34 : SQLSTATE[HY000] [2006] MySQL server has gone away

Questo documento è stato generato automaticamente il 8 janvier 2021.

\section{(c)}

Studi Francesi è distribuita con Licenza Creative Commons Attribuzione - Non commerciale - Non opere derivate 4.0 Internazionale. 


\title{
Alice de Georges-Métral, Poétique de l'excédent dans la narration aurevillienne
}

\author{
Maria Emanuela Raffi
}

\section{NOTIZIA}

ALICE DE GEORGES-MÉTRAL, Poétique de l'excédent dans la narration aurevillienne, dans L.

VERDIER - G. BONNET, L'Excès. Signe ou poncif de la modernité?, Paris, Kimé, 2009, pp. 159-171.

1 In questa stimolante raccolta di saggi dedicati al concetto di «excès», Barbey d'Aurevilly trova un posto non marginale. «L'œuvre romanesque aurevillienne a partie liée avec l'excès par tous ses aspects, le déraisonnable, la débauche, le dérèglement, mais aussi le trop plein, le gaspillage», afferma infatti Alice de Georges-Métral. Tuttavia, aggiunge subito, l'eccesso è il prodotto di un'assenza, di una mancanza e il segno di una ricerca destinata a non essere mai soddisfatta. La poetica dell'eccesso, che Barbey mette in atto nei suoi racconti, e che Alice de Georges-Métral illustra con alcuni esempi dalle Diaboliques, appare sotto il duplice segno della misura da eccedere e dell'assenza di soluzione da rivelare. "Au cœur des nouvelles aurevilliennes, l'excès entre toujours en concurrence avec une mesure à l'aune de laquelle se jauge la démesure qui constitue l'excédent du récit, la part maudite de la diègese, celle d'un mystère qui demeure à jamais irrésolu». Analogamente, lo stile delle novelle mostra, con un cambiamento di ritmo evidente, il passaggio dal sublime al suo rovesciamento nell'orrore, ma non aiuta a rivelare il senso, il cui posto vuoto è forse il segno della modernità. 